\title{
PENGEMBANGAN VIDEO PEMBELAJARAN ANIMASI 2 DIMENSI MATA PELAJARAN AGAMA HINDU MENGENAI SAD RIPU STUDI KASUS KELAS VI (ENAM) SD NEGERI 1 KALIBUKBUK
}

\author{
Putu Wisnu Ekaputra ${ }^{1}$, I Gede Partha Sindu ${ }^{2}$, P Wayan Arta Suyasa ${ }^{3}$ \\ Program Studi Pendidikan Teknik Informatika \\ Jurusan Teknik Informatika \\ Universitas Pendidikan Ganesha \\ Singaraja, Indonesia \\ putuwisnuekaputra19@gmail.com${ }^{1}$, partha.sindu@undiksha.ac.id ${ }^{2}, \underline{\text { arta.suyasa@undiksha.ac.id }}^{\mathbf{3}}$
}

\begin{abstract}
Abstrak- Proses pembelajaran di SD Negeri 1 Kalibukbuk masih menerapkan metode ceramah tanpa adanya alat yang menunjang kegiatan belajar. Guru sudah mampu menerapkan slide presentasi Power Point, namun masih banyak teks yang ditampilkan. Hal tersebut membuat banyak siswa yang kurang fokus dalam mengikuti pembelajaran dan merasa jenuh karena tidak ada yang menarik, sehingga materi oleh guru tidak sepenuhnya tersampaikan dengan baik dan diterima oleh siswa. Peneliti juga melakukan preliminary study berupa analisis kebutuhan yang hasilnya menyatakan bahwa $70 \%$ dari 20 siswa mengalami kesulitan memahami materi yang disampaikan oleh guru dan $80 \%$ dari 20 siswa sangat berminat menggunakan media video pembelajaran dalam proses pembelajaran. Penelitian ini bertujuan untuk mengetahui (1) Rancangan dan implementasi dari Pengembangan Video Pembelajaran Animasi 2 Dimensi Mata Pelajaran Agama Hindu Mengenai Sad Ripu untuk kelas VI di SD Negeri 1 Kalibukbuk. (2) Hasil respon siswa kelas VI terhadap Pengembangan Video Pembelajaran Animasi 2 Dimensi Mata Pelajaran Agama Hindu Mengenai Sad Ripu layak digunakan sebagai media pembelajaran untuk kelas VI SD Negeri 1 Kalibukbuk. Metode penelitian yang digunakan adalah menggunakan pendekatan MDLC (Multimedia Development Life Cycle), dengan melalui beberapa tahapan yaitu concept, design,
\end{abstract}

material collecting, assembly, testing, dan distribution. Hasil penelitian menunjukkan (1) Respon pengguna yaitu siswa sekolah dasar terhadap Video Pembelajaran Animasi 2 Dimensi Mata Pelajaran Agama Hindu Mengenai Sad Ripu mendapatkan respon yang baik dan siswa sangat tertarik dan antusias untuk mempelajari materi Sad Ripu dengan cara menonton video pembelajaran. (2) Dari hasil uji respon siswa terhadap 10 siswa di sekolah dasar yang dijadikan responden dalam melihat uji kelayakan video pembelajaran didapatkan hasil sebesar $85 \%$ yang artinya media video pembelajaran animasi 2 dimensi mata pelajaran agama hindu mengenai sad ripu termasuk pada kategori Baik.

Kata-kata kunci : Video Pembelajaran, Animasi 2D, Agama Hindu, Sad Ripu, MDLC (Multimedia Development Life Cycle).

Abstract- The learning process at SDN 1 Kalibukbuk still uses the lecture method without any utility that supports learning activities. The teacher is able to apply the powerpoint slides, but only display a lot of text. This makes students less focused in the learning process and feel bored because there is nothing interesting, so the material by the teacher is not fully accepted by students. Preliminary study was conducted in the form of a needs analysis, the results stated that $70 \%$ of 20 students had difficulty understanding the material 
presented by the teacher and $80 \%$ of 20 students were very interested in using instructional video in the learning process. The purpose of this study is to determine (1) the design and impementation of the development of a 2-dimentional animation learning video for sad ripu of hindu religion subject for $6^{\text {th }}$ grade at SD Negeri 1 Kalibukbuk. The result of $6^{\text {th }}$ grade response shows that 2-dimentional animation learning video is suitable for learning media of sad ripu of hindu religion subject. Research method used for the development is MDLC (Multimedia Development Life Cycle) approach which contained several steps, they are concept, design, material collecting, assembly, testing, and distribution. Study result shows that the elementary student as user of the learning video gave positive response and very enthusiastic about learning sad ripu of hindu religion subject with learning video. (2) From the result of response test to 10 elementary student as respondent to see the feasibility of learning video obtained result of $85 \%$, which means 2-dimentional animation learning video for sad ripu of hindu religion subject is included in the good category.

Keywords: Learning Video, 2D Animation, Agama Hindu, Hindu Temple

\section{PENDAHULUAN}

Peningkatan pendidikan merupakan upaya yang terus dilaksanakan dan merupakan suatu unsur yang terpenting dalam rangka peningkatan sumber daya manusia. Sejalan dengan itu, hal yang perlu diperhatikan adalah masalah prestasi belajar. Masalah umum yang dihadapi oleh peserta didik adalah masih banyak peserta didik yang belum mendapat nilai yang memuaskan dikarenakan bahan ajar yang ada terbatas pada buku cetak sehingga cenderung berpengaruh terhadap hasil prestasi belajar siswa [1].

Pendidikan agama merupakan aset yang paling penting bagi bangsa atau negara yang mempercayai ketuhanan. Pendidikan agama sudah diajarkan sejak anak mulai tumbuh dan berkembang. Kepercayaan tersebut terbukti dengan adanya pendidikan agama di semua jenjang sekolah mulai dari TK sampai Perguruan Tinggi. Selain itu, orangtua siswa juga merespon positif dengan adanya materi agama yang sudah disajikan secara kompleks diberikan pada setiap sekolah.

Dalam proses pembelajaran di SD Negeri

1 Kalibukbuk, guru mengajar dengan metode ceramah tanpa adanya alat yang menunjang kegiatan belajar. Guru masih menggunakan media buku untuk menjelaskan materi pembelajaran yang ada. Guru di SD Negeri 1 Kalibukbuk juga sudah mampu menerapkan media seperti slide presentasi Power Point, namun kebanyakan guru belum bisa membuat media presentasi yang menarik karena masih banyak teks yang ditampilkan. Hal tersebut membuat banyak siswa yang kurang fokus dalam mengikuti pembelajaran dan merasa jenuh karena tidak ada yang menarik, sehingga materi oleh guru tidak sepenuhnya tersampaikan dengan baik dan diterima oleh siswa.

Media video bertujuan untuk menarik minat belajar siswa dalam memahami materi yang disampaikan agar siswa dapat membayangkan secara langsung materi yang disampaikan. Menurut [2] Media berfungsi sebagai alat penyampaian pesan dari pemberi kepada penerima pesan, media biasanya berupa benda fisik yang didesain secara khusus maupun digunakan apa adanya dengan tujuan menyampaikan pesan dalam pembelajaran. Maka dari itu, pemilihan media dalam proses belajar mengajar memiliki banyak jenisnya tinggal menyesuaikan antara tujuan pembelajaran dengan karakteristik media tersebut. Beragam jenis media yang ada tersebut mengalami perkembangan yang pesat terutama dari segi penyajian yang semakin hari semakin inovatif.

Agama Hindu merupakan salah satu mata pelajaran yang diterapkan di Indonesia dengan tujuan membentuk siswa agar tumbuh dan berkembang menjadi manusia yang beriman dan bertakwa kepada Tuhan Yang Maha Esa serta berakhlak mulia. Banyak materi dalam mata pelajaran Agama Hindu yang dapat diimplementasikan ke dalam media pembelajaran, salah satunya materi yang berkaitan dengan karakter pribadi manusia adalah Sad Ripu. Banyak permasalahan yang terjadi yang berkaitan dengan karakter manusia, contohnya terdapat kasus perkelahian antar pelajar, kasus bullying di sekolah yang mengakibatkan anak putus sekolah. Hal tersebut dikarenakan pelajar tidak mampu mengendalikan emosinya dan hanya mementingkan kepentingan individu tanpa menghiraukan dampak yang terjadi.

Berdasarkan permasalahan yang terjadi dan beberapa solusi yang pernah di tawarkan peneliti sebelumnya perlu adanya media untuk 
menunjang proses pembelajaran agama khususnya Agama Hindu. Dalam rancangan membangun media pembelajaran peneliti berencana mengembangkan media video pembelajaran animasi 2 dimensi mata pelajaran Agama Hindu mengenai Sad Ripu, karena menurut beberapa peneliti sebelumnya media pembelajaran yang paling tepat untuk mengatasi semua permasalahan dalam proses belajar di kalangan anak sekolah dasar adalah media video pembelajaran animasi 2 dimensi.

\section{KAJIAN TEORI}

Penelitian pertama adalah penelitian yang dilakukan [3] dengan judul "Pengembangan Media Pembelajaran Video Animasi 2 Dimensi Berbasis Multimedia Menggunakan Adobe Flash CS6 Pada Mata Pelajaran Bahasa Indonesia Kelas III SD". Hasil dari penelitian ini adalah hasil kualitas media ditinjau dari aspek isi dan aspek pembelajaran berdasarkan ahli materi menunjukkan skor total 82 dengan kriteria baik dan 91 dengan kriteria sangat baik. Hasil kualitas media ditinjau dari aspek desain aplikasi dan komunikasi visual berdasarkan ahli media menunjukkan skor 72 dengan kriteria sangat baik sedangkan berdasarkan angket kualitas produk yang dinilai oleh guru kelas diperoleh presentase 90\% dengan kriteria sangat baik. Hasil respon siswa terhadap penggunaan media diperoleh presentase $91,27 \%$ dengan kriteria sangat tertarik. Hasil respon guru terhadap penggunaan media diperoleh presentase $90 \%$ memiliki kriteria sangat baik. Hasil penelitian sikap siswa terhadap 4 keterampilan mendengarkan, berbicara, membaca, dan menulis berdasarkan hasil observasi pada uji coba kelompok kecil memperoleh skor $62,55 \%$ dengan kriteria cukup. Hasil ketuntasan belajar siswa pada mata pelajaran bahasa Indonesia pada uji coba kelompok besar mencapai skor $82,75 \%$ dengan kriteria baik. Dapat disimpulkan bahwa media video pembelajaran animasi 2D layak digunakan untuk pembelajaran. Penelitian ini digunakan dalam penelitian terkait karena menghasilkan produk video animasi 2 dimensi untuk proses pembelajaran yang efektif serta mengembangkan media pembelajaran pada mata pelajaran Bahasa Indonesia Kelas III.

Penelitian selanjutnya adalah penelitian yang dilakukan oleh [4] dengan judul "Pengembangan Media Video Animasi Pada Pembelajaran Siswa Kelas IV Di Sekolah Dasar. Data dalam penelitian ini dikumpulkan dengan metode wawancara dan tes. Instrument yang digunakan dalam mengumpulkan data yaitu pedoman wawancara dan tes objektif. Tujuan dari penelitian ini dilakukan adalah untu mendeskripsikan rancang bangun video animasi pembelajaran, mendeskripsikan hasil validitas pengembangan video animasi pembelajaran, serta mengetahui efektivitas video animasi pembelajaran yang dikembangkan. Keterkaitan penelitian ini dengan penelitian yang dilaksanakan penulis karena penelitian ini menggunakan media pembelajaran dengan animasi 2 dimensi yang mampu meningatkan hasil belajar siswa sehingga prestasi belajar siswa ikut meningkat.

Penelitian lainnya dilakukan oleh [5] dengan judul "Pengembangan Media Video Animasi Pembelajaran Berbasis Powtoon Pada Kelas 2 Mata Pelajaran Ilmu Pengetahuan Alam Di SD Labschool Unnes". Penelitian ini dilakukan dengan tujuan untuk mengetahui seberapa efektif pengembangan media video animasi pembelajaran. Metode yang digunakan adalah Research and Development (R\&D). selain itu, tujuan dari penelitian ini yaitu sulitnya guru dalam penyampaian materinya yaitu IPA karena kurangnya media pembelajaran sehingga siswa merasa jenuh dan mengganggap IPA pelajaran yang susah dan membosankan. Hasil validasi materi dan tujuan pembelajaran oleh ahli materi sebesar $81,3 \%$ dinyatakan baik, sedangkan ahli media untuk aspek media didapat hasil 93,3\% dan 
untuk aspek tampilan dan hasil produk mendapat hasil $82 \%$ serta untuk aspek kualitas dan keefektifan media diperoleh sebesar $82,22 \%$ dan hasil penilaian oleh siswa untuk aspek tampilan dan keefektifan didapat hasil $89,5 \%$. Maka dapat disimpulkan bahwa media video animasi pembelajaran ini efektif digunakan dalam pembelajaran. Penelitian ini digunakan dalam penelitian terkait karena penelitian ini mengembangkan media video pembelajaran yang memudahkan guru dan siswa untuk mewujudkan pembelajaran yang menyenangkan tanpa mengurangi isi dari materi pelajaran yang sedang disampaikan.

Berikutnya penelitian yang dilakukan oleh [6] dengan judul "Pengembangan Media Film Pembelajaran Menggunakan Animasi 2 Dimensi Pada Mata Pelajaran IPA Kelas V Di Madrasah Ibtidalah". Tujuan dari dilakukannya penilitian ini yaitu untuk mengetahui media film pembelajaran yang tepat dan mampu meningkatkan hasil belajar pada mata pelajaran IPA kelas V Daur Air. Hasil penelitian ini menunjukkan bahwa desain yang tepat adalah dengan menggunakan bermacam-macam warna agar anak-anak tertarik dan tidak bosan dalam menggunakan media pembelajaran. Nilai rata-rata siswa yang menggunakan media film pembelajaran menggunakan animasi 2 dimensi yaitu 74,80, sedangkan rata-rata siswa sebelum menggunakan media film adalah 65,50. Berdasarkan hasil penelitian, disimpulkan bahwa pembelajaran dengan menggunakan media film pembelajaran menggunakan animasi 2 dimensi efektif pada siswa kelas $\mathrm{V}$ di MI Al Islam Mangunsari. Dengan adanya media ini siswa dapat memahami sesuatu yang rumit dan sulit dijelaskan guru secara lisan. Penelitian ini digunakan dalam penelitian terkait karena yaitu ketertarikan dan antusias siswa dalam pembelajaran pada mata pelajaran IPA menggunakan media video animasi sehingga siswa lebih memahami pembelajaran tersebut dan tidak merasa bosan selama pembelajaran tersebut.

Penelitian terkait lainnya dilakukan oleh [7] dengan judul "Media Pembelajaran Mengenal Perangkat Keras Komputer untuk Siswa Kelas IV SDN Tugu Utara 07 Pagi”. Tujuan dari penelitian ini adalah untuk membantu guru menyiapkan media yang menarik agar siswa mampu memahami pembelajaran tentang pengenalan perangkat keras komputer. Pada penelitian ini digunakan metode MDLC atau Multimedia Development Life Cycle. MDLC merupakan metode pengembangan sistem multimedia dengan enam tahapan yaitu Concept, Design, Material Collecting, Assembly, Testing dan Distribution. Hasil dari penelitian ini menunjukkan bahwa Media Pembelajaran Mengenal Perangkat Keras Komputer dapat meningkatkan motivasi belajar siswa. Hal tersebut berdasarkan hasil kuisioner yang diberikan kepada 20 siswa dengan jumlah 10 pertanyaan dan paling banyak menghasilkan respon positif. Kelebihan dari penelitian ini yaitu media yang dikembangkan dapat meningkatkan motivasi belajar siswa sedangkan kekurangan dari penelitian ini yaitu tidak adanya presentase hasil respon siswa terhadap media yang dikembangkan. Penelitian ini digunakan dalam penleitian terkait karena penelitian ini menggunakan metode Multimedia Development Life Cycle, dimana metode MDLC merupakan metode pengembangan media khusus produk multimedia. Metode ini juga memiliki tahapan yang sederhana sehingga memudahkan peneliti dalam pengembangan media pembelajaran.

\section{METODOLIGI PENELITIAN}

Pengembangan Video Pembelajaran Animasi 2D Mata Pelajaran Agama Hindu Mengenai Sad Ripu Studi Kasus Kelas VI (enam) SD Negeri 1 Kalibukbuk menggunakan metode penelitian dan pengembangan (Research and Development). Research and Development 
(R\&D) merupakan metode penelitian yang digunakan untuk menghasilkan produk tertentu. Penelitian ini bertujuan untuk mengembangkan sebuah Video Pembelajaran Animasi 2 Dimensi Mata Pelajaran Agama Hindu Mengenai Sad Ripu.

Pada penelitian ini, model pengembangan yang digunakan adalah model MDLC (Multimedia Development Life Cycle). MDLC merupakan salah satu model pengembangan multimedia versi Luther. Model pengembangan MDLC terdiri dari enam tahap yaitu concept, design, material collecting, assembly, testing, dan distribution.

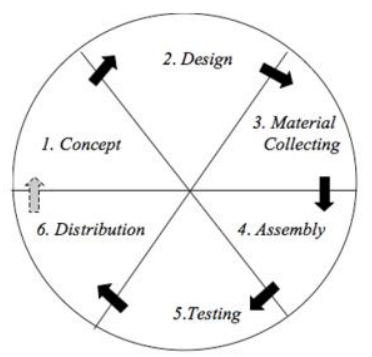

Gambar 1. Tahapan pada model MDLC Sumber: Binanto (2018)

1. Fase Pengonsepan (concept)

Tahap konsep ini merupakan tahapan awal yang dilakukan dari pengembangan media pembelajaran. Proses yang dilakukan pada tahap ini yaitu penentuan ide atau konsep awal dalam mengembangkan video pembelajaran yang dilakukan dengan observasi ke sekolah dan mengumpulkan referensi mengenai pokok bahasan yang diambil. Berdasarkan hasil observasi kelapangan penelitian ini memperoleh aspek analisis konsep kebutuhan.

\section{Fase Perancangan (design)}

Pada tahap desain dilakukan perancangan dari video pembelajaran. Desain merupakan lanjutan dari tahap konsep, dimana hasil analisis media di representasikan ke dalam bentuk desain agar dapat diimplementasikan ketahap selanjutnya menjadi sebuah video pembelajaran. Pada tahap ini, hal yang dilakukan adalah, perancangan ide cerita, pembuatan skenario dalam bentuk sinopsis, dan pembuatan storyboard.

\section{Fase Pengumpulan Materi (Material Collecting)}

Material Collecting adalah tahap
bahan yang sesuai dengan

kebutuhan. Bahan-bahan tersebut antara lain teks, gambar, animasi 2D dan suara baik yang sudah jadi, ataupun yang masih perlu dimodifikasi sesuai dengan kebutuhan yang ada. Bahan-bahan tersebut dapat diperoleh secara gratis atau dengan pemesanan kepada pihak lain sesuai dengan rancangan yang telah dibuat pada tahap sebelumnya.

4. Fase Pembuatan (Assembly)

Tahap Assembly merupakan tahap pembuatan keseluruhan bahan-bahan multimedia. Pada tahap ini, video animasi mulai dikembangkan sesuai dengan yang sudah ditetapkan pada tahap design. Kegiatan yang dilakukan pada tahap Assembly ini adalah produksi dan pasca poduksi. Berikut merupakan tahapan dari kedua proses pembuatan.

1. Produksi, pada tahap ini video pembelajaran animasi 2D dibuat sesuai kebutuhan dari pra produksi yang sudah dirancang. Proses pembuatan karakter dan background 2D pada aplikasi Adobe Illustrator dan Corel Draw X7.

2. Pasca produksi, komposisi dan editing dalam pembuatan sebuah media pembelajaran adalah hal yang sangat utama. Hal ini dikarenakan pada tahap pasca produksi adenganadegan yang sudah dirender kemudian disatukan, disusun dan ditambahkan suara.

\section{Fase Pengujian (Testing)}

Pada tahap ini dilakukan untuk memastikan bahwa seluruh hasil pembuatan video pembelajaran sesuai dengan apa yang sudah direncanakan. Pengujian dilakukan dengan dua tahap yaitu pengujian alpha dan pengujian beta. Pada tahap ini terdapat uji ahli isi dan uji ahli media, uji respon siswa dan uji efektifitas.

\section{Fase Distribusi (Distribution)}

Tahap ini merupakan tahap terakhir dalam tahapan pengembangan video pembelajaran. Setelah tahap pengujian selesai dan layak digunakan, maka dilakukan tahap distribusi. Pada tahap ini, media yang telah dibuat disimpan dalam media penyimpanan berupa Compact Disk (CD). Tahap evaluasi termasuk ke dalam tahap ini. Adanya evaluasi sangat dibutuhkan untuk pengembangan produk yang sudah dibuat sebelumnya agar menjadi lebih baik. 


\section{HASIL DAN PEMBAHASAN}

\section{Hasil}

Pengembangan Video Pembelajaran Animasi 2 Dimensi Mata Pelajaran Agama Hindu mengenai Sad Ripu menggunakan metode penelitian Research and Development (R\&D) dengan model pengembangan MDLC (Multimedia Developmnt Life Cycle), yang terdiri dari enam tahapan, diantaranya adalah concept, design, material collecting, assembly, testing dan distribution. Berikut ini merupakan hasil penelitian menggunakan metode MDLC.

\section{Hasil pengonsepan (concept)}

Di tahap konsep menjelaskan tentang analisis kurikulum dan anilisis media. Berikut tahap analisis kurikulum dan analisis media.

a. Analisis Kurikulum

Pada tahap analisis ini, peneliti menganalisa kurikulum yang berlaku di SD Negeri 1 Kalibukbuk. Setelah mengetahui kurikulum yang berlaku, maka dapat diketahui kompetensi apa yang ingin dicapai pada mata pelajaran Agama Hindu. Di tahap ini peneliti akan mengkaji indikator dan kompetensi dasar pada mata pelajaran Agama Hindu yang akan dijadikan sebagai acuan video pembelajaran animasi 2 Dimensi.

Tabel 1. Analisis Kurikulum

\begin{tabular}{|l|l|l|}
\hline $\begin{array}{l}\text { Materi } \\
\text { Pelajaran }\end{array}$ & $\begin{array}{l}\text { Kompetensi } \\
\text { Dasar }\end{array}$ & Indikator \\
\hline Sad Ripu & $\begin{array}{l}\text { Menerima } \\
\text { ajaran sad ripu } \\
\text { sebagai perilaku } \\
\text { yang harus } \\
\text { dihindari. }\end{array}$ & $\begin{array}{l}\text { Menjelaskan } \\
\text { Pengertian } \\
\text { Sad Ripu }\end{array}$ \\
\cline { 2 - 3 } & $\begin{array}{l}\text { Menunjukan } \\
\text { prilaku } \\
\text { bertanggung } \\
\text { jawab sebagai } \\
\text { wujud } \\
\text { menghindari } \\
\text { sad ripu. }\end{array}$ & $\begin{array}{l}\text { Menyebutkan } \\
\text { jenis - jenis } \\
\text { Sad Ripu }\end{array}$ \\
\cline { 2 - 3 } & $\begin{array}{l}\text { Memahami } \\
\text { ajaran sad ripu } \\
\text { sebagai prilaku } \\
\text { yang harus } \\
\text { dihindari dalam } \\
\text { kehidupan } \\
\text { sehari hari. }\end{array}$ & $\begin{array}{l}\text { Menyebutkan } \\
\text { prilaku Sad } \\
\text { Ripu yang } \\
\text { harus } \\
\text { dihindari }\end{array}$ \\
\hline Menyajikan & Menyebutkan \\
\hline
\end{tabular}

\begin{tabular}{|l|l|l|}
\hline & $\begin{array}{l}\text { contoh prilaku } \\
\text { sad ripu yang } \\
\text { harus } \\
\text { dikendalikan. }\end{array}$ & $\begin{array}{l}\text { larangan - } \\
\text { larangan Sad } \\
\text { Ripu }\end{array}$ \\
\hline
\end{tabular}

b. Analisis Media

Visualisasi yang di kembangkan adalah pemaksimalan teknologi komputer, khususnya dibidang multimedia dalam proses peningkatan pembelajaran Agama Hindu dengan media video pembelajaran animasi 2D, karena media digunakan sebelumnya adalah power point yang hanya berisi tulisan tanpa menampilkan visual.

Tabel 2. Tahap Konsep Video Pembelajaran

\begin{tabular}{|c|c|c|}
\hline No & Konsep & Keterangan \\
\hline 1 & Judul & $\begin{array}{l}\text { Pengembangan } \\
\text { Pembelajaran Animasi } 2 \\
\text { Dimensi Mata Pelajaran } \\
\text { Agama Hindu Mengenai } \\
\text { Sad Ripu "Studi Kasus } \\
\text { Kelas VI SD Negeri 1 } \\
\text { Kalibukbuk" }\end{array}$ \\
\hline 2 & Pengguna & $\begin{array}{lr}\text { Pengguna } & \text { media } \\
\text { pembelajaran } & \text { ini } \\
\text { diperuntukan untuk guru } \\
\text { yang mengampu mata } \\
\text { pelajaran Agama Hindu } \\
\text { materi Sad Ripu dan siswa } \\
\text { kelas VI SD. }\end{array}$ \\
\hline 3 & Tujuan & $\begin{array}{lr}\text { Tujuan } & \text { pembuatan } \\
\text { pengembangan } & \text { video } \\
\text { pembelajaran } & \text { adalah } \\
\text { sebagai berikut, untuk } \\
\text { mengembangkan } \\
\text { Pembelajaran Animasi } 2 \\
\text { Dimensi Mata Pelajaran } \\
\text { Agama Hindu mengenai } \\
\text { Sad Ripu.Untuk dan dapat } \\
\text { mengetahui respon siswa } \\
\text { terhadap } \\
\text { Pembelajaran Animasi } 2 \\
\text { Dimensi Mata Pelajaran } \\
\text { Agama Hindu mengenai } \\
\text { Sad Ripu. }\end{array}$ \\
\hline 4 & $\begin{array}{l}\text { Jenis } \\
\text { Media }\end{array}$ & $\begin{array}{l}\text { Jenis media yang dibuat } \\
\text { adalah berupa } \\
\text { animasi } 2 \text { dimensi. }\end{array}$ \\
\hline
\end{tabular}




\begin{tabular}{|l|l|l|}
\hline 5 & $\begin{array}{l}\text { Pedoman } \\
\text { Materi }\end{array}$ & $\begin{array}{l}\text { Isi materi pembelajaran } \\
\text { mengacu pada sumber buku } \\
\text { Agama Hindu yang } \\
\text { diberikan oleh guru Agama } \\
\text { Hindu kelas IV SDN 1 } \\
\text { Kalibukbuk }\end{array}$ \\
\hline 6 & Audio & $\begin{array}{l}\text { Aplikasi yang digunakan } \\
\text { untuk merekam dan } \\
\text { memperbaiki kualitas suara } \\
\text { yakni Adobe Audition dan } \\
\text { setelah selesai dikonversi } \\
\text { dalam format *.MP3 dan } \\
* \text {.WAV }\end{array}$ \\
\hline 7 & Video & $\begin{array}{l}\text { Menggunakan file yang } \\
\text { berformat .MP4 dibuat } \\
\text { dengan Adobe Premiere } \\
\text { ProCC 2018. }\end{array}$ \\
\hline 8 & $\begin{array}{l}\text { Hasil akhir pengembangan } \\
\text { media pembelajaran ini } \\
\text { berupa kepingan CD/DVD } \\
\text { yang akan diberikan ke } \\
\text { pihak sekolah tempat } \\
\text { penelitian. Dan link } \\
\text { youtube untuk menonton } \\
\text { dalam pros pembelajaran } \\
\text { online }\end{array}$ \\
& Output \\
& & \\
& &
\end{tabular}

2. Hasil Fase Perancangan (design)

Tahap kedua dari metode penelitian MDLC adalah tahap desain. Pada tahap desain terdiri dari kegiatan penyusunan struktur isi dan penyusunan garis-garis besar dari media yang dalam hal ini berbentuk video pembelajaran. Tahap design mendapatkan hasil berupa ide cerita, scenario, storyboard video pembelajaran yang sudah di setujui oleh Nyoman Semadi selaku guru agama SD Negeri 1 Kalibukbuk.

\section{Hasil Fase Pengumpulan Bahan (Material Collecting) \\ Selanjutnya adalah tahap Material Collecting} yaitu pengumpulan pengumpulan bahan yang sesuai dengan kebutuhan. Bahan-bahan tersebut antara lain teks, gambar, animasi 2D dan suara baik yang sudah jadi, ataupun yang masih perlu dimodifikasi sesuai dengan kebutuhan yang ada. Berikut adalah rincian pengumpulan bahan yang digunakan yaitu sebagai berikut:

a. Proses Perekaman Audio (Dubbing)

Pada tahap dubbing, dilakukan proses perekaman yang akan di gunakan untuk pengisi suara karakter 2D dan Narator. Pengisi suara untuk Narator diisi oleh Putu
Wisnu Ekaputra sebagai Kak Tirta. Proses perekaman suara dilakukan pada aplikasi Adobe Audition.

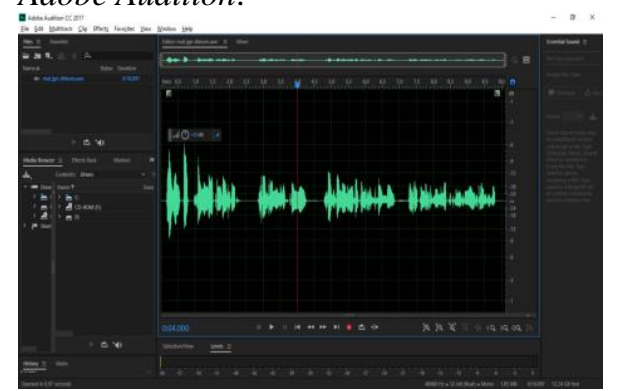

Gambar 2. Proses Editing

b. Pembuatan karakter 2 Dimensi

Karakter 2 Dimensi dalam video pembelajaran Sad Ripu menggunakan aplikasi Adobe Illustrator CC yang memiliki rancangan beberapa karakter animasi yang sudah di design sesuai dengan rancangan karakter dapat ditampilkan pada gambar dibawah ini:

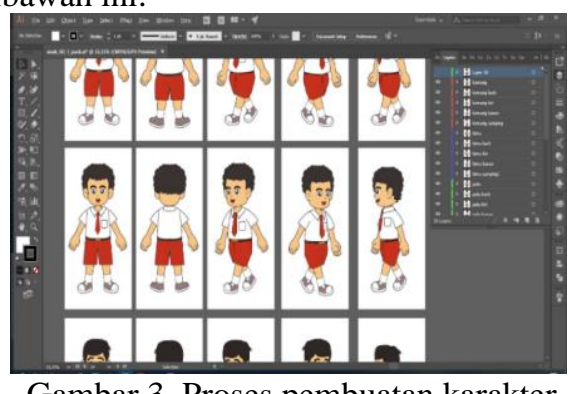

Gambar 3. Proses pembuatan karakter

4. Hasil Fase Pembuatan (Assembly)

Pada tahap pembuatan, kegiatan yang dilakukan pembuatan video pembelajaran yang berupa animasi 2 Dimensi sesuai dengan stroryboard yang dibuat sebelumnya. Pembuatan animasi ini dimulai dengan 2 fase pengembangan yaitu fase produksi dan pasca produksi.

a. Fase Produksi

1. Tahap animasi

Tahap ini dimulai dari meng-import file yang sudah di kumpulkan seperti background, dubbing, karakter pada setiap scene yang dibuat. Proses animasi dilakukan dengan menggunakan perangkat lunak Adobe Animate CC 2020. Adapun tahapan pembuatan animasi dapat dilihat pada gambar berikut ini: 


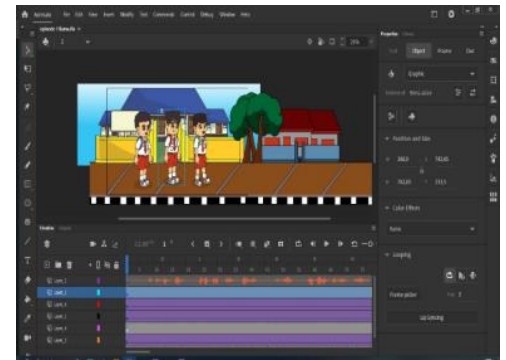

Gambar 4. Tahap Penggabungan Animasi

2. Tahap rendering awal

Setelah pembuatan animasi selesai, proses terakhir adalah export animation menjadi ke dalam file video yang berformat .MP4. Pada tahap ini, tiap-tiap scene dibuat satu persatu dari scene 1 sampai scene akhir untuk mempermudah pada proses editing pada fase pasca-produksi nanti. Tahapan rendering awal dapat dilihat pada gambar berikut ini:

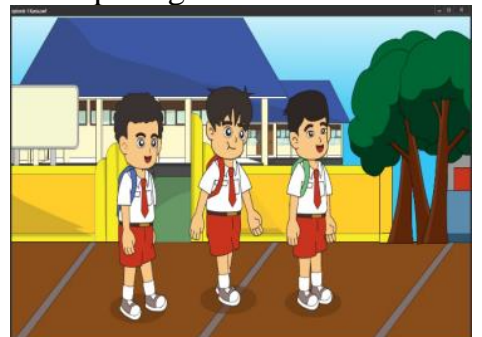

Gambar 5. Tahap Rendering Awal

b. Fase Pasca Produksi

Fase Pasca Produksi bisa dilakukan jika fase produksi sudah selesai dibuat. Hal yang dilakukan pada fase ini, yaitu:

1. Tahap Editing Video

Pada tahap ini, dilakukan penggabungan file video 2 bagian Sad Ripu menjadi satu video utuh yang menjadi suatu Episode. Episode yang dibuat berjumlah tiga episode yang masing-masingnya menjelaskan 2 bagian Sad Ripu. Selain penggabungan video, dilakukan juga penambahan efek suara, efek transisi dan juga penambahan suara latar. Proses ini dilakukan di Adobe Premiere Pro CC 2018.

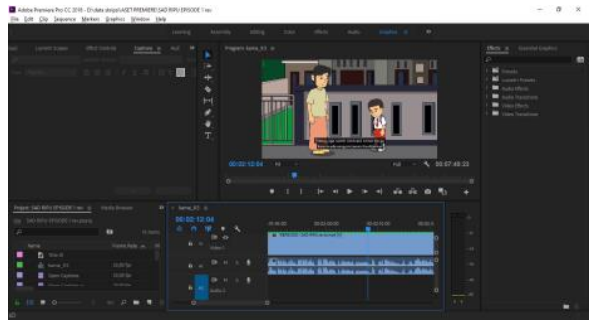

Gambar 6. Tahap Editing Video

2. Tahap Rendering video akhir

Pada tahap ini, setelah proses editing video selesai, maka dilanjutkan dengan penggabungan semua scene menjadi satu file video dan audio yang utuh. Adapun setting yang digunakan peneliti adalah format H.264

1. Hasil Fase Pengujian (Testing)

Pada tahap ini dilakukan pengujian pada media yang dibuat. Pada tahap testing, terdapat 2 Uji Ahli Isi, 2 Uji Ahli Media, Uji Efektifitas, dan Uji Respon Siswa. Untuk pengujian tersebut juga dibuatkan sebuah instrumen penelitian. Instrumen yang digunakan pada penelitian ini berupa angket untuk Ahli Isi, Ahli Media, dan Uji Respon.

a. Hasil ahli isi/materi

Uji validitas isi instrument ahli isi dilakukan dengan guru dan dosen Agama Hindu, dalam hal ini dilibatkan dua narasumber, yaitu Guru Agam Hindu di SD Negeri 1 Kalibukbuk dan Staf Dosen Undiksha. Hasil perhitungan sebagai berikut.

Validasi isi $=\frac{\mathrm{D}}{\mathrm{A}+\mathrm{B}+\mathrm{C}+\mathrm{D}}=\frac{10}{10}=1.00$

Jadi Tingkat Validitas isi nilai 1,00 berada pada tingkat validitas "Sangat Tinggi".

b. Uji Ahli Media

Uji ahli media dan desain difungsikan sebagai dasar acuan untuk mengetahui kesesuaian materi yang akan disampaikan melalui video pembelajaran yang sudah dibuat dan secara teknis pada pembuatan visual dan audio video. Dalam uji ahli media peneliti melibatkan dua dosen dari Jurusan Pendidikan Teknik Informatika Undiksha. Hasil perhitungan sebagai berikut.

Validasi isi $=\frac{\mathrm{D}}{\mathrm{A}+\mathrm{B}+\mathrm{C}+\mathrm{D}}=\frac{11}{12}=0,916$ 
Jadi Kriteria Tingkat Validitas media dan desain nilai 0,916 berada pada tingkat validitas "Sangat Tinggi". sehingga dinyatakan layak untuk digunakan.

c. Uji Respon Siswa

Uji respon penonton dilakukan setelah video selesai dibuat untuk melihat respon siswa terhadap Video Pembelajaran Animasi 2D Mengenai Sad Ripu. Tahap ini dilakukan untuk mengetahui tanggapan siswa terhadap video yang telah dibuat. Uji respon penonton telah dilakukan dengan melibatkan 10 orang responden yang diambil menggunakan google form, pada tanggal 17 Juli sampai 18 Juli 2021. Berdasarkan data respon siswa terhadap media video pembelajaran Agama Hindu untuk siswa kelas VI sekolah dasar adalah 85\% sudah memenuhi kriteria Sangat Baik. Kesimpulannya, tingkat respon dari siswa terhadap media pembelajaran Agama Hindu sangat baik dan layak untuk digunakan untuk proses belajar. pembelajaran serta diharapkan dapat meningkatkan pemahaman siswa terhadap materi mata pelajaran agama hindu mengenai materi Sad Ripu. Berdasarkan hasil observasi dan wawancara yang dilakukan di SD Negeri 1 Kalibukbuk, sebagian besar guru sudah mampu menerapkan media presentasi Power Point namun media presentasi yang disajikan masih kurang menarik Hal tersebut membuat banyak siswa mengalami kurang fokus, cepat bosan dan jenuh karena pemberian materi yang terlihat monoton dan kurang menarik selama proses pembelajaran, sehingga materi yang diberikan guru tidak sepenuhnya tersampaikan dengan baik dan diterima oleh siswa. Berdasarkan hal tersebut, dikembangkanlah suatu media video pembelajaran animasi 2 dimensi pada mata pelajaran Agama Hindu mengenai Sad Ripu untuk membantu meningkatkan pemahaman siswa terhadap materi Sad Ripu selama proses pembelajaran.

Penelitian pengembangan media video pembelajaran animasi 2D ini menggunakan

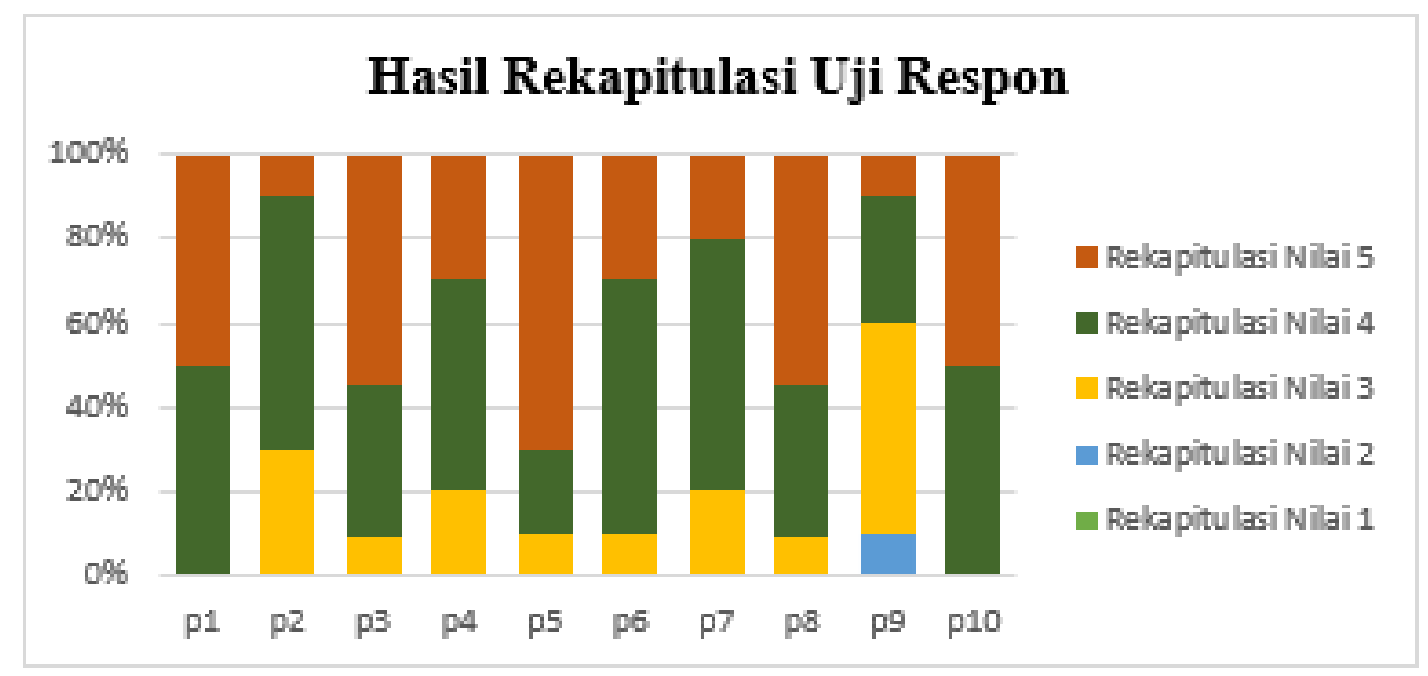

Gambar 7. Rekapitulasi Uji

\section{Hasil Tahap Distribusi (Distribution)}

Tahap akhir yaitu pendistribusian setelah hasil uji yang menyatakan layak maka video pembelajaran ini akan di distribusikan menggunakan $\mathrm{CD} /$ flashdisk untuk distribusi offline dan online bisa menggunakan youtube.

\section{Pembahasan}

Pengembangan media pembelajaran animasi 2 dimensi pada mata pelajaran agama hindu memiliki tujuan untuk membantu proses model MDLC, dimana ada 6 tahapan yang harus dilalui yaitu 1. Concept; 2. Design; 3. Material Collecting; 4. Assembly; 5. Testing; 6. Distribution. Berdasarkan model penelitian yang digunakan, tahap pertama yang dilakukan yaitu tahap konsep (consept) dimana pada tahap ini dilakukan kegiatan analisis kurikulum dan analisis media.

Tahap kedua adalah perancangan (design) dimana tahap hasil analisis media yang telah diperoleh di representasikan ke dalam bentuk 
desain agar dapat diimplementasikan ketahap selanjutnya menjadi sebuah video pembelajaran. Pada tahap desain, hal yang dilakukan yaitu berupa perancangan ide cerita, pembuatan skenario dalam bentuk sinopsis, dan pembuatan storyboard. Skenario pada penelitian ini berupa sebuah naskah cerita/sinopsis. Kemudian pada perancangan storyboard, dirancang gambaran dari scene, bentuk visual perancangan, suara, durasi, keterangan dan narasi yang diimplementasikan ke dalam video pembelajaran yang dikembangkan.

Tahap ketiga yaitu pengumpulan bahan materi (material collecting) yang dibutuhkan dalam pengembangan meliputi pengumpulan bahan-bahan antara lain teks, gambar, animasi 2 Dimensi dan suara baik yang sudah jadi, ataupun yang masih perlu dimodifikasi sesuai dengan kebutuhan yang ada. Bahan-bahan yang digunakan untuk kebutuhan aplikasi diperoleh dari membuat sendiri dengan menggunakan Adobe Illustrator, Adobe Animate CC 2020, Corel Draw X7, Adobe Audition, Adobe Premiere Pro, serta beberapa bahan yang diambil dari internet yang kemudian diolah dengan perangkat lunak yang telah disebutkan sebelumnya. Pada tahapan ini terdapat 3 kegiatan yang dilakukan yaitu proses perekaman audio, proses pembuatan karakter animasi 2 dimensi dan proses pembuatan background.

Tahap keempat adalah pembuatan (assembly), dimana pada tahap ini dilakukan proses pembuatan media pembelajaran sesuai dengan storyboard yang telah dibuat sebelumnya. Pada tahap pembuatan, kegiatan yang dilakukan meliputi pembuatan video pembelajaran yang berupa animasi 2 dimensi, dimulai dengan 2 fase pengembangan yaitu fase produksi dan pasca produksi. Pada pengembangan fase produksi, terdapat hal-hal yang di proses meliputi tahap animasi dan tahap rendering awal. Kemudian, pada pengembangan fase pasca produksi, dilakukan setelah fase produksi selesai dibuat. Dalam hal ini, sesuai materi yang ada pada Sad Ripu, dibuatkan 3 Episode yang setiap episodenya menjelaskan 2 bagian dari Sad Ripu. Pada tahap pasca produksi juga merupakan tahapan pembuatan seluruh objek berdasarkan perancangan yang telah dibuat sebelumnya. Hal yang dilakukan pada tahap ini yaitu tahap editing video dan tahap rendering akhir.

Tahap kelima adalah pengujian (testing). Setelah selesai melakukan pengembangan media video pembelajaran animasi 2 dimensi, selanjutnya dilakukan tahap validasi atau pegujian media pembelajaran. Tahap pengujian media video pembelajaran animasi 2 dimensi pada mata pelajaran Agama Hindu ini dimulai dari review para ahli yaitu ahli isi dan ahli media. Kemudian dilanjutkan dengan uji efektifitas dan uji respon siswa. Hasil pengujian ahli isi materi dengan menggunakan uji Gregory, berdasarkan angket menunjukkan bahwa tingkat pencapaian dari video pembelajaran yang dikembangkan memperoleh koefisien validitas sebesar 1,00 dan berada pada kriteria "Sangat Tinggi". Hal tersebut mengindikasikan bahwa materi yang diimplementasikan ke dalam video pembelajaran animasi 2 dimensi pada materi Sad Ripu sudah relevan dan layak untuk digunakan dalam pembelajaran.

Hasil pengujian ahli media dengan menggunakan uji Gregory, berdasarkan angket menunjukkan bahwa tingkat pencapaian dari video pembelajaran yang dikembangkan memperoleh koefisien validitas sebesar 0,916 dan berada pada kriteria "Sangat Tinggi". Hasil penilaian ahli media menandakan bahwa produk video pembelajaran animasi 2 dimensi pada materi Sad Ripu yang sudah dikembangkan dinyatakan sangat relevan dan layak untuk digunakan dalam proses pembelajaran Agama Hindu. Menurut [8] bahwa pemanfaatan media yang relevan di dalam kelas dapat mengoptimalkan proses pembelajaran dan membantu mengkonkritkan konsep atau gagasan serta membantu memotivasi peserta belajar aktif. Bagi siswa, video pembelajaran animasi dapat menjadi jembatan untuk berpikir kritis. Hal ini juga di dukung oleh penelitian yang dilakukan [9] yang menyatakan penggunaan video pembelajaran animasi edukatif sangat efektif sebagai media untuk mengembangkan semangat dan motivasi siswa, hal ini ditinjau melalui kriteria pembelajaran video untuk anak, yaitu syarat ideal media pembelajaran video harus memenuhi beberapa kriteria antara lain kejelasan pesan, berdiri sendiri, akrab dengan anak, representasi isi, visualisasi atau kualitas gambar baik dapat digunakan klaisikal maupun individual.

Langkah selanjutnya yaitu melakukan uji efektifitas menggunakan perhitungan $\mathrm{N}$-gain. Berdasarkan hasil pre-test dan hasil post-test siswa terhadap media video pembelajaran diperoleh nilai rata-rata untuk pre-test yaitu 
sebesar 68 dan untuk nilai rata rata post-test yaitu sebesar 85. Maka dapat disimpulkan bahwa terjadi kenaikan rata-rata nilai yang diperoleh siswa setelah melakukan pembelajaran dengan media video pembelajaran animasi 2 dimensi pada mata pelajaran Agama Hindu mengenai Sad Ripu

Tahap terakhir yaitu Uji Respon Siswa, pada uji respon siswa ini menggunakan metode pengukuran menggunakan skala likert. angket uji dibuat dalam bentuk checklist dengan lima skala yaitu Sangat Setuju (SS), Setuju (S), Kurang Setuju (KS), Tidak Setuju (TS), dan Sangat Tidak Setuju (STS). Tahap ini dilakukan untuk mengetahui tanggapan siswa terhadap video yang telah dibuat. Uji respon siswa telah dilakukan dengan melibatkan 10 orang responden yang diambil menggunakan google form, pada tanggal 17 Juli sampai 18 Juli 2021. Hasil persentase data angket respon siswa terhadap media video pembelajaran Agama Hindu mengenai Sad Ripu untuk siswa kelas VI sekolah dasar adalah sebesar $85 \%$. Jika dikonversi ke dalam range presentasi kelayakan video maka hasilnya termasuk dalam kriteria "Baik". Menurut [10] bahwa video pembelajaran memiliki kedudukan sebagai suplemen (tambahan) dalam proses pembelajaran. Artinya, media video pembelajaran yang dikembangkan layak dan efektif mampu meningkatkan pemahanan siswa serta dapat digunakan dalam proses pembelajaran. Penggunaan media pembelajaran berbasis video sangat diminati anak, hasil belajarnya juga lebih baik setelah menggunakan video pembelajaran. Kemampuan anak dalam kategori mengingat, memahami, mengaplikasikan, menganalisis, mengevaluasi dan mencipta dapat meningkat apabila diberikan inovasi pembelajaran berupa aktivitas pembelajaran mengamati berbantuan audiovisual atau video [11].

Berdasakan hasil uji respon siswa terhadap media video pembelajaran Agama Hindu mengenai Sad Ripu untuk siswa kelas VI sekolah dasar adalah sebesar $85 \%$ dan sudah memenuhi kriteria "Baik". Menurut [12] bahwa video pembelajaran membawa dampak positif bagi kegiatan belajar peserta didik seperti demontrasi materi, motivasi, tutorial, dan efektivitas waktu. Berdasarkan hasil perhitungan dan pengujian yang telah dilakukan, maka dapat disimpulkan bahwa media video pembelajaran Agama Hindu mengenai Sad Ripu untuk siswa kelas VI sekolah dasar telah valid (sangat tinggi), keefektifan (cukup efektif) dan kepraktisan (baik).

Tahap keenam yaitu Distribusi (Distribution), pada tahap ini dilakukan dengan 2 metode distribusi, diantaranya yaitu distribusi online dan distribusi offline. Pada tahap distribusi versi online, pengemasan distribusi film ini di upload menjadi 2 bagian, yaitu per episode namun versi online yang akan diupload lewat youtube ini masih belum dapat diakses secara publik. Sedangkan pada tahap distribusi offline, pengemasannya ada yang berupa DVD dan Flash disk (DVD/Flash disk akan berisikan 3 file berupa video dengan format .MP4.

Hasil pengembangan video pembelajaran Agama Hindu mengenai Sad Ripu untuk siswa kelas VI sekolah dasar ini, sejalan dengan penelitian yang dilakukan oleh [4] dengan judul "Pengembangan Media Video Animasi Pada Pembelajaran Siswa Kelas IV Di Sekolah Dasar". Tujuan dari penelitian ini dilakukan adalah untu mendeskripsikan rancang bangun video animasi pembelajaran, mendeskripsikan hasil validitas pengembangan video animasi pembelajaran, serta mengetahui efektivitas video animasi pembelajaran yang dikembangkan. Keterkaitan penelitian ini dengan penelitian yang dilaksanakan penulis karena penelitian ini menggunakan media pembelajaran dengan animasi 2 dimensi yang mampu meningatkan hasil belajar siswa sehingga prestasi belajar siswa ikut meningkat.

Penelitian terkait berikutnya oleh [3] dengan judul "Pengembangan Media Pembelajaran Video Animasi 2 Dimensi Berbasis Multimedia Menggunakan Adobe Flash CS6 Pada Mata Pelajaran Bahasa Indonesia Kelas III SD”. Hasil kualias media berdasarkan penilaian ahli media menunjukkan skor 72 dengan kriteria sangat baik sedangkan berdasarkan angket kualitas produk yang dinilai oleh guru kelas diperoleh presentase $90 \%$ dengan kriteria sangat baik. Hasil berdasarkan respon siswa terhadap penggunaan media diperoleh presentase mencapai 91,27\% dengan kriteria sangat tertarik. Hasil respon guru terhadap penggunaan media diperoleh presentase 90\% memiliki kriteria sangat baik. Hasil observasi pada uji coba kelompok kecil memperoleh skor $62,55 \%$ dengan kriteria cukup. Hasil ketuntasan belajar siswa pada mata pelajaran bahasa Indonesia pada uji coba kelompok besar mencapai skor $82,75 \%$ dengan kriteria baik. Dapat disimpulkan bahwa media 
video pembelajaran animasi 2D layak digunakan untuk pembelajaran. Penelitian ini digunakan dalam penelitian terkait karena menghasilkan produk video animasi 2 dimensi untuk proses pembelajaran yang efektif serta mengembangkan media pembelajaran pada mata pelajaran IPS kelas VII.

Berdasarkan pembahasan di atas, secara garis besar pengembangan video pembelajaran Agama Hindu mengenai Sad Ripu untuk siswa kelas VI sekolah dasar telah memenuhi kriteria kualitas produk yaitu kevalidan, keefektifan dan kepraktisan, sehingga layak untuk digunakan sebagai sumber belajar dan media pembelajaran. Melalui penerapan media video pembelajaran Agama Hindu mengenai Sad Ripu untuk siswa kelas VI sekolah dasar ini diharapkan dapat membantu guru dalam proses pembelajaran dan mampu mengatasi permasalahan yang selama ini dialami dalam proses pembelajaran.

\section{KESIMPULAN}

Kesimpulan yang dapat diperoleh dari pembahasan concept, design, material collecting, assembly dan distribution pada penelitian Video Pembelajaran Animasi 2 Dimensi Mata Pelajaran Agama Hindu Mengenai Sad Ripu Studi Kasus Kelas VI (enam) SD Negeri 1 Kalibukbuk, yaitu.

Pengembangan Video Pembelajaran Animasi 2 Dimensi Mata Pelajaran Agama Hindu Mengenai Sad Ripu Studi Kasus Kelas VI (enam) SD Negeri 1 Kalibukbuk menggunakan model penelitian MDLC (Multimedia Development Life Cycle). Video pembelajaran ini menceritakan tentang materi pengertian bagian-bagian dan hal yang harus dikendalikan dari Sad Ripu dalam Mata Pelajaran Agama Hindu. Pembuatan video pembelajaran animasi 2 dimensi ini, peneliti menggunakan beberapa aplikasi yaitu: Adobe Illustrator, Adobe Animate, Adobe Audition, Corel Draw X7 dan Adobe Premiere.

Respon pengguna yaitu siswa sekolah dasar terhadap Video Pembelajaran Animasi 2 Dimensi Mata Pelajaran Agama Hindu Mengenai Sad Ripu mendapatkan respon yang Baik. Siswa sangat tertarik dan antusias untuk mempelajari materi Sad Ripu dengan cara menonton video pembelajaran.

Dari hasil uji respon siswa terhadap 10 siswa di sekolah dasar yang dijadikan responden dalam melihat uji kelayakan video pembelajaran didapatkan hasil sebesar $85 \%$ yang artinya media video pembelajaran animasi 2 dimensi mata pelajaran agama hindu mengenai sad ripu termasuk pada kategori Baik.

\section{REFERENSI}

[1] Khotimah. (2017). Hubungan Media Pembelajaran Dan Sumber Belajar Dengan Hasil Belajar Siswa Mata Pelajaran SBK Materi Gambar Ilustrasi SD Gugus Ahmad Yani Boyolali. Digilib Unnes, 1(2), 111.

[2] Putri, W. N. (2017). Pengaruh Media Pembelajaran Terhadap Motivasi Belajar Bahasa Arab Siswa Madrasah Tsanawiyah. Journal of Arabic Education and Literature, 1(1), 1-16.

[3] Anisa \& Sunarti. (2016). Pengembangan Media Pembelajarana Video Animasi 2D Berbasis Multimedia Menggunakan Adobe Flash CS6 Pada Mata Pelajaran Bahasa Indonesia Kelas 3 SD. Jurnal Universitas PGRI Yogyakarta, 1(1), 2-4.

[4] Jerry, Jampel, \& Sudarma. (2018). Pengembangan Media Video Animasi Pada Pembelajaran Siswa Kelas IV Di Sekolah Dasar. E-Journal Edutech Universitas Pendidikan Ganesha, 6(1), 9-19.

[5] Adkhar. (2016). Pengembangan Media Video Animasi Pembelajaran Berbasis Powtoon Pada Kelas 2 Mata Pelajaran Ilmu Pengetahuan Alam di SD Labschool Unnes. Digilib Unnes, 1(2) 1-39.

[6] Manik. (2017). Pengembangan Media Film Pembelajaran Menggunakan Animasi 2 Dimensi Pada Mata Pelajaran IPA Kelas V Di Madrasah Ibtidaiah. Digilib Unnes, 1(2), 1-28.

[7] Mulia \& Sugiarto. (2017). Media Pembelajaran Mengenal Perangkat Keras Komputer Untuk Siswa Kelas IV SDN Tugu Utara 07 Pagi. SIMNASIPTEK, 1(1) 76-83

[8] Karo-Karo, I. R., \& Rohani. (2018). Manfaat Media Dalam Pembelajaran. Jurnal Pendidikan dan Matematika, 7(1), 91-95.

[9] Miranda, D. (2019). Pengembangan Video Animasi Berbasis Karakter Cinta Tanah Air Untuk Anak Usia Dini. Jurnal Visi Ilmu Pendidikan, 11(2), 12. https://doi.org/10.26418/jvip.v11i2.32565.

[10] Hidayati, A., Adi, E., \& Praherdhiono, H. (2019). Bangan Media Video Pembelajaran Untuk Meningkatkan Pemahaman Materi Gaya Kelas Iv Di Sdn Sukoiber 1 Jombang. JINOTEP (Jurnal Inovasi Dan Teknologi Pembelajaran) Kajian Dan Riset Dalam Teknologi Pembelajaran, 6(1), 45-50. https://doi.org/10.17977/um031v6i12019p045.

[11] Dewi, L. M. I., \& Rimpiati, N. L. (2016). Efektivitas penggunaan media pembelajaran video interaktif dengan seting diskusi. Jepun, 1(1), 31-46..

[12] Agustini, K., \& Ngarti, J. G. (2020). Pengembangan Video Pembelajaran Untuk Meningkatkan Motivasi Belajar Siswa Menggunakan Model R \& D. Jurnal Ilmiah Pendidikan Dan Pembelajaran, 62-78. https://doi.org/http://dx.doi.org/10.23887/jipp.v4i1.1 8403. 